OPEN

SUBJECT AREAS:

FISHERIES

ECOSYSTEM ECOLOGY

Received

29 October 2014

Accepted

10 February 2015

Published

12 March 2015

Correspondence and requests for materials should be addressed to M.G.M. (m.meekan@ aims.gov.au)

* Current address: Alfred Wegener Institute Helmholtz

Centre for Polar and

Marine Research,

Building E-2155, Am

Handelshafen 12, D-

27570 Bremerhaven,

Germany.

\section{Growth of a deep-water, predatory fish is influenced by the productivity of a boundary current system}

\author{
Hoang Minh Nguyen', Adam N. Rountrey 2,3, Jessica J. Meeuwig',2, Peter G. Coulson ${ }^{4}$, Ming Feng ${ }^{5}$, \\ Stephen J. Newman ${ }^{6}$, Anya M. Waite ${ }^{7 *}$, Corey B. Wakefield ${ }^{6}$ \& Mark G. Meekan ${ }^{8}$
}

\begin{abstract}
${ }^{1}$ School of Animal Biology, University of Western Australia, Crawley WA, Australia, ${ }^{2}$ Centre for Marine Futures, Oceans Institute, University of Western Australia, Crawley WA, Australia, ${ }^{3}$ Museum of Paleontology, University of Michigan, Ann Arbor MI, USA, ${ }^{4}$ Centre for Fish and Fisheries Research, School of Veterinary and Life Sciences, Murdoch University, Murdoch WA, Australia, ${ }^{5}$ CSIRO Oceans \& Atmosphere Flagship, Underwood Avenue, Floreat, WA 6014, Australia, ${ }^{6}$ Western Australian Fisheries and Marine Research Laboratories, Department of Fisheries, Government of Western Australia, PO Box 20, North Beach, WA 6920, Australia, ${ }^{7}$ School of Civil, Environmental and Mining Engineering, University of Western Australia, Crawley WA, Australia, ${ }^{8}$ Australian Institute of Marine Science, Crawley WA, Australia.
\end{abstract}

The effects of climate change on predatory fishes in deep shelf areas are difficult to predict because complex processes may govern food availability and temperature at depth. We characterised the net impact of recent environmental changes on hapuku (Polyprion oxygeneios), an apex predator found in continental slope habitats ( $>200 \mathrm{~m}$ depth) by using dendrochronology techniques to develop a multi-decadal record of growth from otoliths. Fish were sampled off temperate south-western Australia, a region strongly influenced by the Leeuwin Current, a poleward-flowing, eastern boundary current. The common variance among individual growth records was relatively low $(3.4 \%)$, but the otolith chronology was positively correlated $(r=0.61, p<0.02)$ with sea level at Fremantle, a proxy for the strength of the Leeuwin Current. The Leeuwin Current influences the primary productivity of shelf ecosystems, with a strong current favouring growth in hapuku. Leeuwin Current strength is predicted to decline under climate change models and this study provides evidence that associated productivity changes may flow through to higher trophic levels even in deep water habitats.

D emersal fishes that occupy relatively deep waters (around $200 \mathrm{~m}$ ) at the edge of the continental shelf are likely to be particularly vulnerable to the alterations in marine ecosystems predicted to occur under scenarios of climate change in the near future (50-100 years). In part, this vulnerability is due to strong associations with the seabed that may constrain their ability to move around barriers created by inappropriate habitats (see Part C in reference 1). They are also thought to be at risk because such species tend to be targets of major commercial fisheries, so that in many cases, their populations are already heavily exploited ${ }^{1-4}$. Thus, climate change may act on species that already have populations with limited resilience due to over-harvest.

Our ability to predict the responses of deep water fishes to climate change is complicated by their trophic role as secondary carnivores or apex predators. For such species, productivity input into the ecosystem can be modified by a complex web of interactions and energy flows occurring in lower parts of the food chain that can take place remotely, in pelagic or shallow water ecosystem $s^{5,6}$. Furthermore, species in deep water are removed from the direct effects of changes in some physical variables such as sea surface temperature. The difficulty in determining the likely effects of climate change on deep water fishes has been acknowledged as a major challenge for research (as reviewed in Ref. 7).

Although there is a growing number of studies e.g. ${ }^{8-12}$ that examine how increasing sea surface temperatures may affect the distribution and abundance of marine fishes, climate change may also lead to modification of ocean circulation and changes in the primary productivity of the ocean $\mathrm{s}^{13-15}$. Simultaneous changes to multiple aspects of marine systems mean that it is difficult to predict net impacts and to envisage how these might influence individual-level variables, such as growth rate, which will integrate this complex interplay of drivers. In part, this is due to a lack of long-term (decadal) observational data sets sufficient to investigate the relationships between vital rates of fishes in natural environments and variation in climate. 
Recent studies show that growth records from otoliths may be particularly useful in filling this knowledge gap ${ }^{16}$. This research applies techniques developed in dendrochronology (the study of tree-rings) to data extracted from otoliths so that growth records from many fish can be aligned and combined into a single timeseries $^{17}$. This allows enhancement of the population "signal" (i.e. the common growth response to regional environmental drivers, such as temperature, productivity and current flow) above individual variation.

Here, we use a dendrochronology approach to construct and analyse long-term (decadal) growth records of the hapuku (Polyprion oxygeneios), a large (up to $175 \mathrm{~cm}$ ) predatory teleost typically found at the shelf edge in depths of $200-850 \mathrm{~m}^{18,19}$. Our focus is on individuals collected from a region of relatively rapid warming off the south-west of Western Australia ${ }^{20,21}$. Not only is the region warming, but models suggest that there will be substantial changes to regional oceanography in this century, including weakening of the Leeuwin Current ${ }^{22,23}$, which exerts a major influence on the productivity of the coast of $\mathrm{WA}^{22}$. We identify key environmental drivers of growth rate for this apex, deep-water predator and consider the implications of environmental conditions predicted to occur in the near future (within 50 years) on the growth of this species.

\section{Results}

Our sample included fish from 27 to 49 years of age. A spline rigidity with a $50 \%$ frequency cut-off of nine years (see Supplementary Notes S1) was selected for standardizing measurements from transects before averaging transects for each individual. The mean sensitivity (a measure of high frequency variation, see Ref. 24) of individual mean series (IMS) was 0.14 , indicating a relatively low degree of interannual variation in increment widths.

In order to identify a segment of the mean index chronology (MIC) with adequate signal representation, we used the criterion that the value obtained from subtracting two times the standard error from $\bar{r}$ (the mean of the pairwise correlations among all series excluding correlations of series with themselves) must be greater than 0 for a 15-year segment. The 15-year periods of 1989-2003, 1990-2004 and 1991-2005 had $\bar{r}-2$ s.e. greater than 0 (Fig. 1), and we chose to focus on the period of 1990-2004 (Fig. 2) because a larger number of pairwise correlations were included in the $\bar{r}$ calculation relative to other segments. The expressed population signal (EPS, see Supplementary Notes S1) for the 1990-2004 period was 0.60 with

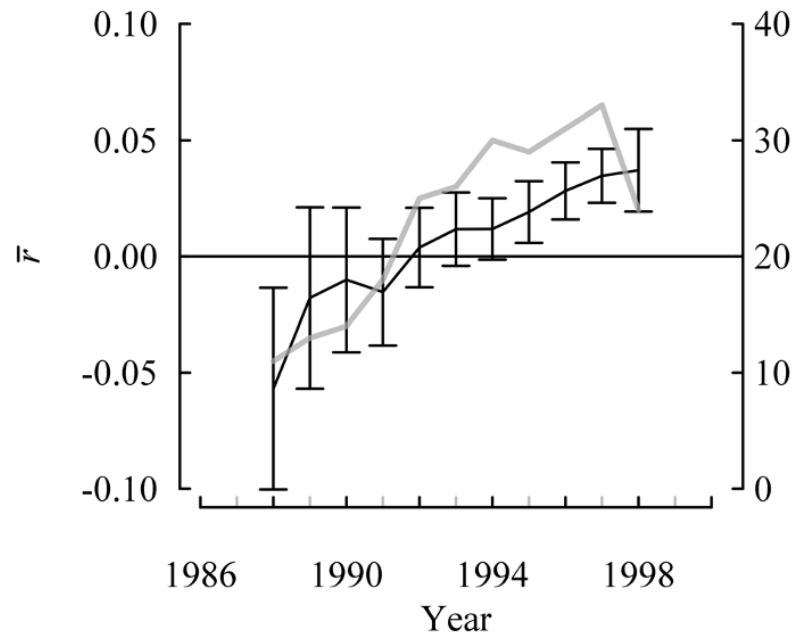

Figure 1 | Pairwise correlations among all series excluding selfcorrelations $(\bar{r}) \pm$ s.e.(black line) and number of individual 15 -year series contributing to the calculation (sample depth, grey line). Values are plotted at the centres of the 15-year intervals. The 1997 (i.e., 1990-2004) segment was used to assess the influence of environmental factors.

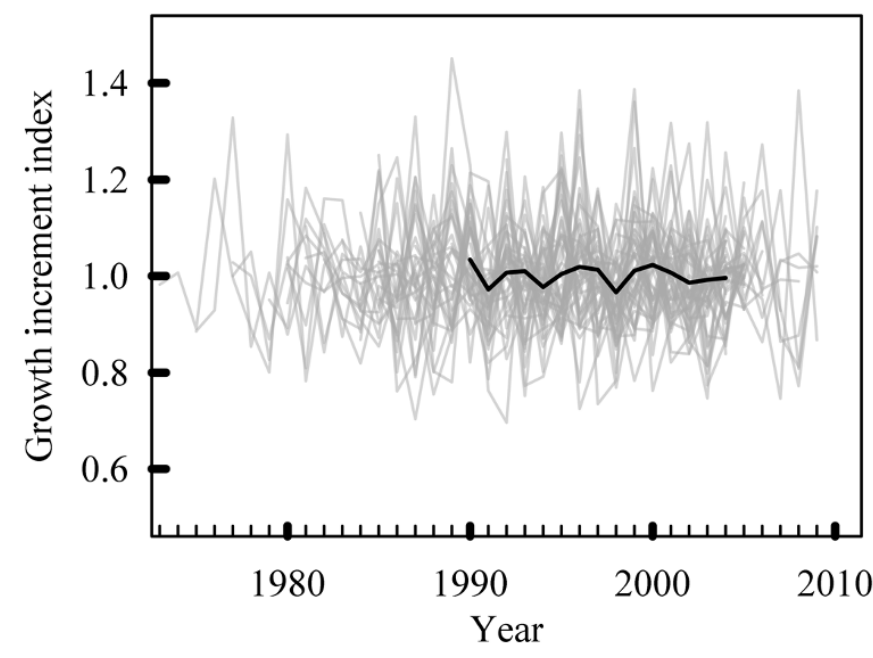

Figure $2 \mid$ Individual mean series (IMS, grey lines) of otolith growth for the 44 hapuku after detrending using a spline with a $50 \%$ frequency cutoff of nine years, and the mean index chronology (MIC, black line) covering the selected 15-year period.

a $\bar{r}$ of 0.035 (s.e. $=0.012$ ). The MIC for this period was used in all subsequent analyses.

Correlation tests with environmental variables revealed significant correlations $(\mathrm{p}<0.05)$ with the Multivariate El Niño/Southern Oscillation Index (MEI) $(r=-0.62)$, Fremantle sea level $(r=$ 0.61 ), and sea surface temperatures in austral autumn, winter, and spring of the previous year (Table 1). There were no significant correlations with variables in the year of growth (Table 1).

\section{Discussion}

The Leeuwin Current as a driver of growth of a deep-water predator. Growth of hapuku (as measured by the mean index chronology from 1990-2004) was positively correlated with the previous year's mean annual sea level at Fremantle, which is a proxy for the strength of the Leeuwin Current through El NiñoSouthern Oscillation cycles ${ }^{25,26}$. Given that this current exerts a major influence over sea surface temperature and productivity of shelf waters off south-western Australia ${ }^{22}$, this correlation likely reflects a relationship between growth of this species and a number of oceanographic/ecological processes occurring within the Current system. In austral autumn and winter, the Leeuwin Current intensifies and produces mesoscale $(2-100 \mathrm{~s}$ of $\mathrm{km})$ eddies $^{27}$ that spin up just beyond the shelf break ${ }^{28-30}$. Warm core eddies increase the instability of the Current and destratify the water column, flooding the shelf-break with relatively nutrient-rich waters sourced from the shelf itself ${ }^{29}$ during austral autumn and winter (March-August). Cold-core eddies move deep nutrient-rich water to the surface via upwelling ${ }^{27}$. Both warm and cold core eddies therefore contribute an offshore component to the regional increase in primary production commencing in March and peaking in May $^{27,29,31}$.

The delay between the response of hapuku growth in one year and the period of peak productivity induced by the Leeuwin Current in the preceding $\mathrm{May}^{26,29}$ is probably caused by the transfer time required for increases in productivity to reach upper trophic levels of the food chain upon which hapuku prey. Analyses of gut contents of hapuku indicate that squid (most likely arrow squid, Nototodarus gouldi, S. Leporati pers. comm.) are a major (>50\%) component of the diet (C. Wakefield pers. comm.; ${ }^{32}$ ). Squid typically show strong diel cycles of vertical migration, ascending at night to the thermocline and surface waters to feed on invertebrates and small fishes and descending to deep waters during the day ${ }^{33}$. This pattern of migration 
Table 1 | Correlations between the 1990-2004 mean index chronology and environmental variables. "Previous year" indicates the correlation between the 1990-2004 mean index chronology and environmental data from 1989-2003. Significant correlations are bolded and indicated by asterisks

\begin{tabular}{|lccccc} 
Variable & Season & Current year $r$ & $p$ & Previous year $r$ & $p$ \\
\hline Detrended annual Fremantle sea level & - & 0.23 & 0.415 & $* \mathbf{0 . 6 1}$ & $\mathbf{0 . 0 1 6}$ \\
Annual Multivariate ENSO Index & - & -0.19 & 0.500 & $*-\mathbf{0 . 6 2}$ & $\mathbf{0 . 0 1 4}$ \\
Annual Dipole Mode Index & - & -0.35 & 0.195 & -0.21 & 0.445 \\
"Perth" sea surface temperature & DJF & 0.42 & 0.120 & 0.018 & 0.948 \\
& MAM & 0.02 & 0.941 & $* \mathbf{0 . 6 2}$ & $\mathbf{0 . 0 1 5}$ \\
& JA & -0.33 & 0.236 & 0.47 & 0.080 \\
"Albany" sea surface temperature & SON & 0.14 & 0.621 & 0.51 & 0.053 \\
& DJF & 0.49 & 0.062 & 0.15 & 0.591 \\
& MAM & 0.32 & 0.246 & 0.46 & 0.086 \\
"Esperance" sea surface temperature & JJA & 0.25 & 0.371 & $* \mathbf{0 . 1}$ & $\mathbf{0 . 0 1 5}$ \\
& SON & -0.18 & 0.527 & $* \mathbf{0}$ & $\mathbf{0 . 0 1 7}$ \\
& DJF & 0.21 & 0.447 & -0.19 & 0.502 \\
& MAM & 0.38 & 0.158 & 0.18 & 0.510 \\
& JJA & -0.04 & 0.879 & $* \mathbf{0 . 5 6}$ & $\mathbf{0 . 0 2 9}$ \\
& SON & 0.07 & 0.799 & 0.4 & 0.137 \\
\hline
\end{tabular}

allows squid to form part of a relatively simple pelagic food chain, so that energy flows to deep apex predators are likely to be far more direct and rapid than if they were to pass through more complex benthic habitats. Squid also have relatively short life spans and their growth rates can respond very rapidly to changes in ocean conditions, with increased growth occurring in association with increased productivity and temperature ${ }^{34}$. Thus, squid may allow for fast transfer of productivity from the surface to large, deepwater predators. The lag between increased hapuku growth and the proximate impacts of a strengthened Leeuwin Current is likely to reflect the time required for prey to attain the sizes where they form a substantial part of the hapuku diet.

Hapuku growth was negatively correlated with MEI of the previous year and positively correlated with SST in the previous year (Table 1). The negative correlation with MEI, which indicates higher growth rates following La Niña years, is not surprising given that the Leeuwin Current is stronger during La Niña years ${ }^{26}$. Positive correlations of hapuku growth with SST in the previous year reflect the strong link between the Leeuwin Current and SST. It is unclear how direct effects (e.g. physiological) of environmental temperature could produce substantially lagged growth responses, and other studies have not shown such lags ${ }^{35-38}$. This supports the hypothesis that the growth of hapuku was driven by changes in productivity of the system (for which a lag would be expected), rather than by the direct effects of changes in water temperature.

Hapuku growth and climate change. Ocean temperatures in Western Australia are predicted to rise by 0.5 to $1.0^{\circ} \mathrm{C}$ at depths down to $500 \mathrm{~m}$, according to the CSIRO's Mk 3.5 climate change model and the atmospheric $\mathrm{CO}_{2}$ scenario of 536 ppm by 2050 (See Parts A and B in Ref. 1). While this moderate increase in temperature may have some direct impact on the growth of deep-dwelling fish like hapuku, it is possible that the larger impacts of climate change will eventuate through decreases in productivity associated with changes in regional oceanography. Subsurface cooling in the Western Equatorial Pacific, along with weakened Pacific trade winds and increased sea surface salinity, suggest that the strength of the Leeuwin Current will decrease over the next 100 years ${ }^{23,30}$. Downscale modelling from the CSIRO mark 3.5 model by Sun, et al..$^{39}$ shows that these declines in current strength could be as great as $15 \%$ by the 2060s, with the largest decreases occurring in austral winter. Given the link between enhancement of primary productivity induced by the Leeuwin Current and the growth of hapuku, our study suggests that growth rates may decrease in the future, potentially impacting the fishery.
In summary, our study provides evidence of a link between the growth of deep water, predatory fishes and regional oceanographic processes. It contrasts with other work that has largely focused on the direct effects of changes in SST on the distribution and abundance of fishes e.g. ${ }^{10,35,37}$. The strength of the relationship between growth and the Leeuwin Current that we described may be a consequence of the trophic role of hapuku as a higher-order predator, with a diet that focuses on fast-growing forage species with strong links to relatively simple food chains in the pelagic environment that in turn rely on regional primary productivity. This suggests that other deep-water

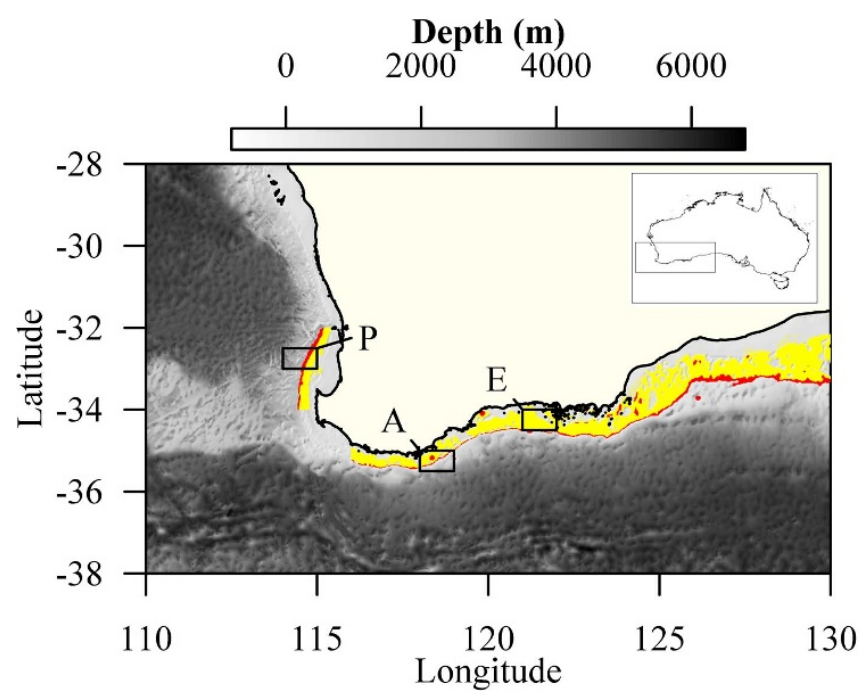

Figure $3 \mid$ Southwestern Australia showing areas in which study fish were caught. Red highlighting indicates areas of the shelf corresponding to the depth of capture (200-450 m); yellow highlighting indicates other areas of the shelf with appropriate depth range for the species (50-200 m). Some localized deep areas on the southern shelf may represent errors in bathymetry data. Black rectangles mark grid cells for which sea surface temperature was extracted- $\mathrm{P}=$ "Perth", $\mathrm{A}=$ = "Albany", $\mathrm{E}=$ "Esperance". Inset shows location of detail map. Figure 3 was generated using $R$ vers. 2.15.2 (R Foundation for Statistical Computing, Vienna, Austria), the PBSmapping package vers. $2.67 .60^{57}$ and the marmap package ${ }^{58}$. The bathymetric data were from the global, self-consistent, hierarchical, highresolution geography database (GSHHG) vers. 2.2.0 $0^{59}$ and the coastal data NOAA 1 Arc-Minute Global Relief Model ${ }^{60}$. 


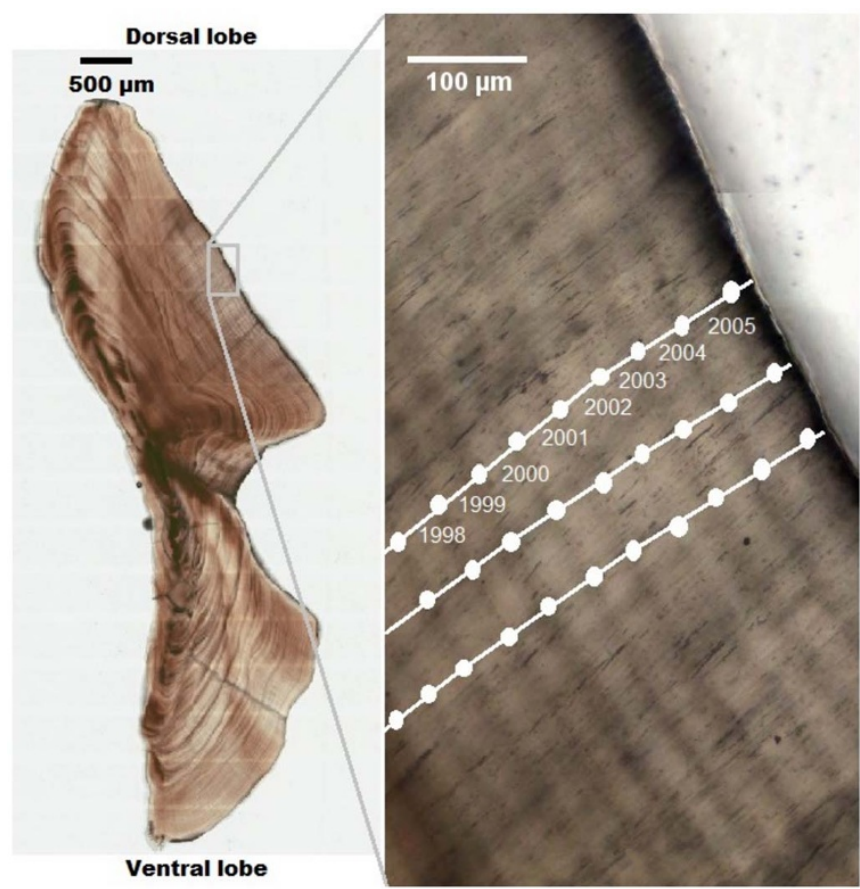

Figure $4 \mid$ Transmitted light image of a sectioned otolith from a 32-yearold hapuku. The magnified section shows the dorsal mid-lobe region where opaque zones were marked (white circles) and increments were measured along three transects (white lines). Numbers identify the year in which the increments were formed.

species that rely on squid or other vertically migrating prey in the region may show similar responses to variations in Leeuwin Current strength.

Our study shows that otolith biochronologies provide a relatively simple means to determine the drivers of growth of marine fishes in deep water on the shelf slope that are remote from some of the other physical effects of climate change such as warming sea-surface temperatures. These biochronologies can be used to examine relative influence on growth of both physical and biological factors, even when the study species is a high-order predator at the upper end of the food chain.

\section{Methods}

Study species. Hapuku have a circumglobal distribution between $28^{\circ} \mathrm{S}$ and $43^{\circ} \mathrm{S}$, and individuals are typically found between depths of $50-450 \mathrm{~m}^{18,40}$, with most animals typically occurring at depths greater than $200 \mathrm{~m}$. Adult hapuku range in size from around $70 \mathrm{~cm}$ to over $175 \mathrm{~cm}$ in total length ${ }^{19}$. The species is classified as an 'opportunistic generalized carnivore ${ }^{41}$ and has an unusual life history in that juveniles have a protracted (3-4 years) pelagic stage during which they associate with flotsam ${ }^{42}$ This stage provides a potential mechanism for long-range mixing among populations separated by thousands of kilometres.

Hapuku are long-lived, with a maximum observed age of 63 years for fish in New Zealand waters and 52 years for fish in waters off south-western Australia ${ }^{19,42}$ although fish over 20 years of age are relatively uncommon ${ }^{42}$. Their long lifespan enables compilation of a growth chronology covering decades using individuals captured over just several years. The age of maturation (for $50 \%$ of individuals) of both sexes is around seven years and spawning occurs from May to September in south-western Australia ${ }^{19}$. Growth rates of juveniles and adults are highest between January and May, although growth occurs throughout the year at lower rates ${ }^{19}$

Otolith analysis. Hapuku otoliths were obtained from the collections of the Department of Fisheries of Western Australia. Otolith sections (see Ref. 19) were produced from fish caught between 2005 and 2011 by commercial fishers employing multi-hooked vertical drop lines in 200 to $450 \mathrm{~m}$ waters off the south $\left(115.5^{\circ} \mathrm{E}\right.$ to $129.0^{\circ} \mathrm{E}$ ) and south-west $\left(32.0^{\circ} \mathrm{S}\right.$ to $\left.34.0^{\circ} \mathrm{S}\right)$ coasts, respectively (Fig. 3). Otoliths from the 50 oldest individuals were selected for analysis to maximize temporal coverage. Sections were scanned using transmitted light on an Aperio Scanscope ${ }^{\mathrm{TM}}$ (Aperio

Technologies Inc., Vista, California, USA). Six sections were excluded due to issues associated with increment clarity.

Increment widths were measured using a polyline-transect-based measurement plugin ${ }^{43}$ for ImageJ vers. $1.45 \mathrm{~s}$ (U.S. National Institute of Health, Bethesda, Maryland, USA). Beginning at the periphery of the otolith and moving toward the primordium, a polyline transect was placed such that the line segments remained locally parallel to the direction of growth, i.e. perpendicular to the increment pattern (Fig. 4). Marks were placed at the middle of each opaque zone. Partial years at the outermost edge of the otolith section were excluded from the measurement series.

Increments were measured along three to five transects in each otolith to increase reliability. While it was possible to use the whole otolith section to count all opaque zones from the periphery to the primordium to establish ages for each individual, it was not possible to precisely measure the widths of all growth increments due to the unclear boundaries of increments corresponding to the first 10-12 years of life, a time that included changes in morphology associated with the transition from pelagic to deep water habitats ${ }^{44}$. For this reason measurements were restricted to increments formed after the age of 12 so that all measured increments represented growth in sexually mature individuals ${ }^{19}$.

Biochronology development. A mean index chronology (MIC) was developed from the chronologies of the 44 fish by firstly crossdating, which aided the alignment of increment data to calendar years using the program $\mathrm{COFECHA}{ }^{45}$. Chronologies were then detrended using R vers. 2.15.2 (R Foundation for Statistical Computing, Vienna, Austria) and the dplR package (dendrochronology program library in R) ${ }^{46,47}$ with some additional scripts. This involved removing ontogenetic trends and averaging the resulting series to increase the signal-to-noise ratio ${ }^{48}$. Initially, the increment measurement series from each transect was detrended (standardized) by dividing the series by a cubic smoothing spline with a $50 \%$ frequency cut off ${ }^{49,50}$ of 22 years ${ }^{17,37}$. For each fish, an individual mean series (IMS) was calculated by averaging the standardized indices from the three or five transects. The Pearson's correlation coefficient between each IMS and the mean of all other IMSs was calculated. The mean of those correlation coefficients is the interseries correlation, a measure of the strength of the common signal. Additional details on this procedure and the process used to select a final detrending scheme can be found in the Supporting Information

Table 2 | Summary of environmental variables used in correlation tests. Abbrev.: lat: latitude; lon: longitude; Per: Perth; Alb: Albany, and Esp: Esperance. Sources: Met Office Hadley Centre ${ }^{51}$; BOM: Bureau of Meteorology, Australia ${ }^{52}$; JAMSTEC: Japanese Agency for Marine-Earth Science and Technology ${ }^{53}$; NOAA/PSD: National Oceanic and Atmospheric Administration/Physical Science Division: Earth System Research Laboratory ${ }^{54}$

\begin{tabular}{|c|c|c|c|c|c|c|c|}
\hline Environmental Variable & Units & Temporal resolution & Grid Type & \multicolumn{3}{|c|}{ Grid Cell Locations } & Source \\
\hline Sea surface temperature (HadISST) & ${ }^{\circ} \mathrm{C}$ & seasonal means & $1^{\circ}$ & $\begin{array}{l}\text { Per } \\
\text { Alb } \\
\text { Esp }\end{array}$ & $\begin{array}{l}-32.5 \\
-35.5 \\
-34.5\end{array}$ & $\begin{array}{l}114.5 \\
118.5 \\
121.5\end{array}$ & Met Office Hadley Centre \\
\hline Fremantle sea level (linear detrended) & $\mathrm{m}$ & annual mean & - & - & - & - & $\mathrm{BOM}$ \\
\hline
\end{tabular}

Indian Ocean Dipole (IOD) $)^{55}$

annual mean

JAMSTEC

Multivariate ENSO Index (MEI) ${ }^{56}$

annual mean

NOAA/PSD 
Note S1. After crossdating and detrending, the program ARSTAN (Autoregressive Standardization $)^{48}$ was used to obtain a MIC that accounted for autocorrelation.

Several environmental variables and climate indices were compiled in order to determine their potential influence on hapuku growth (Table 2). Pearson's correlation coefficients were used to investigate the relationship between the MIC and annual or seasonal means of these variables and indices. As the growth of an annual increment in an otolith represents the growth that occurred from approximately November through October (the "growth year") ${ }^{19}$, increment measurements were assigned to the calendar year in which most growth represented in that increment occurred. We refer to this as the "current calendar year". For the correlation tests, we included environmental values from the current calendar year and the previous calendar year to allow for the detection of the effects of the prior year's environmental conditions on growth. For gridded environmental datasets, we selected grid cells close to three locations along the lower west and south coasts of Western Australia: offshore Perth $\left(-32.5^{\circ}, 114.5^{\circ}\right)$, Albany $\left(-35.5^{\circ}, 118.5^{\circ}\right)$, and Esperance $\left(-34.5^{\circ}, 121.5^{\circ}\right)$ (Fig. 3).

1. Hobday, A. J., Okey, T. A., Poloczanska, E. S., Kunz, T. J. \& Richardson, A. J. Impacts of climate change on Australian marine life in CSIRO Marine and Atmospheric Research report to the Australian Greenhouse Office, Department of the Environment and Heritage. (eds Hobday, A. J. et al.) (CSIRO Marine and Atmospheric Research, Canberra, 2006).

2. Pauly, D., Christensen, V., Dalsgaard, J., Froese, R. \& Torres, F. Fishing down marine food webs. Science 279, 860-863 (1998).

3. Morato, T., Watson, R., Pitcher, T. J. \& Pauly, D. Fishing down the deep. Fish Fish. 7, 24-34 (2006).

4. Wakefield, C. B., Newman, S. J. \& Boddington, D. K. Exceptional longevity, slow growth and late maturation infer high inherent vulnerability to exploitation for bass groper Polyprion americanus (Teleostei: Polyprionidae). Aquat. Biol. 18, 161-174 (2013).

5. Hannides, A. K. \& Smith, C. R. Chapter 10: The northeastern Pacific abyssal plain. in Biogeochemistry of Marine Systems. (eds Black, K. D. \& Shimmield, G. B.) 208-237 (Blackwell Science, Oxford, , UK, 2003).

6. Smith, C. R., Levin, L. A., Koslow, A., Tyler, P. A. \& Glover, A. G. The near future of deep seafloor ecosystem in Aquatic ecosystems: trends and global prospects. (ed. Polunin, N. V. C.) 334-351 (Cambridge University Press, Cambridge, UK, 2008).

7. Glover, A. G. et al. Temporal change in deep-sea benthic ecosystems: a review of the evidence from recent time-series studies. Adv. Mar. Biol. 58, 1-95 (2010).

8. Cheung, W. W. L. et al. Projecting global marine biodiversity impacts under climate change scenarios. Fish Fish. 10, 235-251 (2009).

9. Cheung, W. W. L. et al. Large-scale redistribution of maximum fisheries catch potential in the global ocean under climate change. Global Change Biol. 16, 24-35 (2010).

10. Burrows, M. T. et al. The pace of shifting climate in marine and terrestrial ecosystems. Science 334, 652-655 (2011).

11. Johnson, J. E. \& Holbrook, N. J. Adaptation of Australia's marine ecosystems to climate change: Using science to inform conservation management. Int. J. Ecol. 2014, 12 pages (2014).

12. Lu, H.-J. \& Lee, H.-L. Changes in the fish species composition in the coastal zones of the Kuroshio Current and China Coastal Current during periods of climate change: Observations from the set-net fishery (1993-2011). Fish. Res. 155 103-113 (2014).

13. Alley, R. B. et al. Abrupt climate change. Science 299, 2005-2010 (2003).

14. Bryden, H. L., Longworth, H. R. \& Cunningham, S. A. Slowing of the Atlantic meridional overturning circulation at $25^{\circ} \mathrm{N}$. Nature 438, 655-657 (2005).

15. Behrenfeld, M. J. et al. Climate-driven trends in contemporary ocean productivity. Nature 444, 752-755 (2006).

16. Morrongiello, J. R., Thresher, R. E. \& Smith, D. C. Aquatic biochronologies and climate change. Nature Clim. Change 2, 849-857 (2012).

17. Black, B. A., Boehlert, G. W. \& Yoklavich, M. M. Using tree-ring crossdating techniques to validate annual growth increments in long-lived fishes. Can. J. Fish. Aquat. Sci. 62, 2277-2284 (2005).

18. Barreiros, J. P., Machado, L., Hostim-Silva, M., Sazima, L. \& Heemstra, P. C. First record of Polyprion oxygeneios (Perciformes: Polyprionidae) for the south-west Atlantic and a northernmost range extension. J. Fish Biol. 64, 1439-1441 (2004).

19. Wakefield, C. B., Newman, S. J. \& Molony, B. W. Age-based demography and reproduction of hapuku, Polyprion oxygeneios, from the south coast of Western Australia: implications for management. ICES J. Mar. Sci. 67, 1164-1174 (2010).

20. Cheung, W. W. L. et al. Climate-change induced tropicalisation of marine communities in Western Australia. Mar. Freshwat. Res. 63, 415-427 (2012)

21. Pearce, A. \& Feng, M. Observations of warming on the Western Australian continental shelf. Mar. Freshwat. Res. 58, 914-920 (2007).

22. Feng, M., Waite, A. M. \& Thompson, P. A. Climate variability and ocean production in the Leeuwin Current system off the west coast of Western Australia. J. R. Soc. West. Aust. 92, 67-81 (2009).

23. Hobday, A. J. \& Lough, J. M. Projected climate change in Australian marine and freshwater environments. Mar. Freshwat. Res. 62, 1000-1014 (2011).

24. Fritts, H. C. Tree rings and climate. (Academic Press, New York, 1976).

25. Pearce, A. F. \& Phillips, B. F. ENSO events, the Leeuwin Current and larval recruitment of the western rock lobster. J. Conseil 45, 13-21 (1988).
26. Feng, M., Meyers, G., Pearce, A. \& Wijffels, S. Annual and interannual variations of the Leeuwin Current at $32^{\circ}$ S. J. Geophys. Res. (C Oceans) 108, 1-21 (2003).

27. Waite, A. M. et al. The Leeuwin Current and its eddies: An introductory overview. Deep Sea Res. (II Top. Stud. Oceanogr.) 54, 789-796 (2007).

28. Feng, M., Wijffels, S., Godfrey, S. \& Meyers, G. Do eddies play a role in the momentum balance of the Leeuwin Current? J. Phys. Oceanogr. 35, 964-975 (2005).

29. Koslow, J. A. et al. The effect of the Leeuwin Current on phytoplankton biomass and production off Southwestern Australia. J. Geophys. Res. (C Oceans) 113, 1-19 (2008).

30. Feng, M., Weller, E. \& Hill, K. The Leeuwin Current in A marine climate change impacts and adaptation report card for Australia 2009. (eds Poloczanska, E. S., Hobday, A. J. \& Richardson, A. J. ) (NCCARF Publication 05/09, Cleveland, QLD, 2009).

31. Hanson, C. E., Pattiaratchi, C. B. \& Waite, A. M. Seasonal production regimes off south-western Australia: influence of the Capes and Leeuwin Currents on phytoplankton dynamics. Mar. Freshwat. Res. 56, 1011-1026 (2005).

32. Goldman, S. F. \& Sedberry, G. R. Feeding habits of some demersal fish on the Charleston Bump off the southeastern United States. ICES J. Mar. Sci. 68, 390-398 (2011).

33. Boyle, P. \& Rodhouse, P. Oceanic and deep-sea species in Cephalopods: ecology and fisheries.176-228 (Blackwell Publishing, Oxford, UK, 2005).

34. Jackson, G. D. \& Domeier, M. L. The effects of an extraordinary El Niño/La Niña event on the size and growth of the squid Loligo opalescens off Southern California. Mar. Biol. 142, 925-935 (2003).

35. Matta, M. E., Black, B. A. \& Wilderbuer, T. K. Climate-driven synchrony in otolith growth-increment chronologies for three Bering Sea flatfish species. Mar. Ecol. Prog. Ser. 413, 137-145 (2010).

36. Black, B. A., Allman, R. J., Schroeder, I. D. \& Schirripa, M. J. Multidecadal otolith growth histories for red and gray snapper (Lutjanus spp.) in the northern Gulf of Mexico, USA. Fish. Oceanogr. 20, 347-356 (2011).

37. Gillanders, B. M., Black, B. A., Meekan, M. G. \& Morrison, M. A. Climatic effects on the growth of a temperate reef fish from the Southern Hemisphere: a biochronological approach. Mar. Biol. 159, 1327-1333 (2012).

38. Rountrey, A. N., Coulson, P. G., Meeuwig, J. J. \& Meekan, M. Water temperature and fish growth: otoliths predict growth patterns of a marine fish in a changing climate. Global Change Biol. 20, 2450-2458 (2014).

39. Sun, C. et al. Marine downscaling of a future climate scenario for Australian boundary currents. J. Clim. 25, 2947-2962 (2012).

40. Paxton, J. R., Hoese, D. F., Allen, G. R. \& Hanley, J. E. Pisces. Petromyzontidae to Carangidae zoological catalogue of Australia. Vol. 7 (Australian Government Publishing Service, Canberra 1989).

41. Roberts, C. D. Hapuku and bass: the mystery of the missing juveniles. Seafood $N$. Z. 4, 17-21 (1996)

42. Francis, M. P., Mulligan, K. P., Davies, N. M. \& Beentjes, M. P. Age and growth estimates for New Zealand hapuku, Polyprion oxygeneios. Fish. Bull. 97, 227-242 (1999).

43. Rountrey, A. N. Life histories of juvenile woolly mammoths from Siberia: stable isotope and elemental analyses of tooth dentin. Doctor of Philosophy thesis, University of Michigan, Ann Arbor, (2009).

44. Machias, A. et al. Settlement of the wreckfish (Polyprion americanus). Mar. Biol. 142, 45-52 (2003).

45. Holmes, R. L. Computer-assisted quality control in tree-ring dating and measurement. Tree-Ring Bull. 43, 69-78 (1983).

46. Bunn, A. G. A dendrochronology program library in R (dplR). Dendrochronologia 26, 115-124 (2008).

47. Bunn, A. G. Statistical and visual crossdating in R using the dplR library. Dendrochronologia 28, 251-258 (2010).

48. Cook, E. R. A time-series analysis approach to tree-ring standardization, University of Arizona, (1985)

49. Grissino-Mayer, H. D. Evaluating crossdating accuracy: A manual and tutorial for the computer program COFECHA. Tree-Ring Res. 57, 205-221 (2001).

50. Cook, E. R. \& Peters, K. The smoothing spline: a new approach to standardizing forest interior tree-ring width series for dendroclimatic studies. Tree-Ring Bull. 41, 45-53 (1981).

51. Rayner, N. A. et al. Global analyses of sea surface temperature, sea ice, and night marine air temperature since the late nineteenth century. J. Geophys. Res. 108, 4407 (2003).

52. Bureau of Meteorology. Monthly sea levels for Fremantle - 1897 to 2010. (2010) Available at: http://www.bom.gov.au/ntc/IDO70000/IDO70000_62230_SLD. shtml. (Accessed: $16^{\text {th }}$.July 2012)

53. Japanese Agency for Marine-Earth Science and Technology. SST DMI dataset (monthly from 1958 to 2010) derived from HadISST dataset. (2012) Available at http://www.jamstec.go.jp/frsgc/research/d1/iod/e/iod/dipole_mode_index.html. (Accessed: 24 $4^{\text {th }}$ July 2012).

54. Earth System Research Laboratory. Multivariate ENSO Index (MEI). (2012) Available at: http://www.esrl.noaa.gov/psd/enso/mei/table.html. (Accessed: $24^{\text {th }}$ July 2012).

55. Saji, N. H., Goswami, B. N., Vinayachandran, P. N. \& Yamagata, T. A dipole mode in the tropical Indian Ocean. Nature 401, 360-363 (1999).

56. Wolter, K. \& Timlin, M. S. Monitoring ENSO in COADS with a seasonally adjusted principal component index. in $17^{\text {th }}$ Climate Diagnostics Workshop. 52-57 
(NOAA/NMC/CAC, NSSL, Oklahoma Climate Survey, CIMMS and the School of Meteorology, University of Oklahoma, Norman, OK, 1993).

57. Schnute, J. T. et al. PBSmapping: mapping fisheries data and spatial analysis tools. (2014) Available at: http://CRAN.R-project.org/package=PBSmapping. (Accessed: $3^{\text {rd }}$ December 2014).

58. Pante, E. \& Simon-Bouhet, B. marmap: A package for importing, plotting and analyzing bathymetric and topographic data in R. PLoS ONE 8, e73051 (2013).

59. Wessel, P. \& Smith, W. H. F. A global self-consistent, hierarchical, high-resolution shoreline database. J. Geophys. Res. 101, 8741-8743 (1996).

60. Amante, C. \& Eakins, B. W. ETOPO1 1 arc-minute global relief model: procedures, data sources and analysis. NOAA Technical Memorandum NESDIS NGDC-24(2009). doi:10.7289/V5C8276M. (Accessed: $3^{\text {rd }}$ December 2014).

\section{Acknowledgments}

This work was supported by a grant from the Australian National Network in Marine Science. Samples and logistical support were provided by the Department of Fisheries, Western Australia.

\section{Author contributions}

J.J.M., M.G.M., S.J.N. and H.M.N. conceived the study. H.M.N., A.N.R., P.G.C., J.J.M., M.G.M., S.J.N. and C.B.W. contributed to study design, material collection, laboratory work, data analysis and manuscript preparation, editing and improvement. M.F. and A.M.W. contributed to the data analysis, discussion, manuscript editing and improvement.

\section{Additional information}

Supplementary information accompanies this paper at http://www.nature.com/ scientificreports

Competing financial interests: The authors declare no competing financial interests.

How to cite this article: Nguyen, H.M. et al. Growth of a deep-water, predatory fish is influenced by the productivity of a boundary current system. Sci. Rep. 5, 9044; DOI:10.1038/ srep09044 (2015).

This work is licensed under a Creative Commons Attribution 4.0 International License. The images or other third party material in this article are included in the article's Creative Commons license, unless indicated otherwise in the credit line; if the material is not included under the Creative Commons license, users will need to obtain permission from the license holder in order to reproduce the material. To view a copy of this license, visit http://creativecommons.org/licenses/by/4.0/ 